\title{
Impact of para-neurologic and para-mental premorbidities on burn injury patients
}

\author{
Yanık hastalarında nörolojik ve mental morbiditelerin etkisi
}

\author{
Mehmet BOZKURT, ${ }^{1}$ Emin KAPI, ${ }^{1}$ Ercan GEDİK, ${ }^{2}$ Samet Vasfi KUVAT ${ }^{1}$
}

\section{BACKGROUND}

The aim of this article was to determine whether there are differences in the progression, mortality and morbidity of these premorbid patients compared to normal burn injury patients.

\section{METHODS}

In this study, 26 premorbid cases ( 8 males, 18 females; mean age: 30.8 years; range: $3-74$ years) hospitalized in the Dicle University Burn Center between July 2007 and November 2009 were evaluated.

\section{RESULTS}

Appreciation of the pathophysiological basis of the premorbidity in burn patients is important. When the treatment for premorbid burn patients is planned, the associated co- or premorbidity must be kept in mind. To improve the outcome of the treatment, considerable attention must be paid to these patients.

\section{CONCLUSION}

This article gives an overview of the current literature regarding premorbid patients in the Turkish population and draws attention to this specific topic.

Key Words: Burn; complication; premorbidity.

\section{AMAÇ}

$\mathrm{Bu}$ yazının amacı, normal yanık travmalı hastalara göre ek morbiditeli hastaların gidişat, mortalite ve morbiditelerinde farkların olup olmadığının saptanmasıdır.

\section{GEREC VE YÖNTEM}

Bu çalışmada, Temmuz 2007 ve Kasım 2009 tarihleri arasında Dicle Üniversitesi Yanık Merkezi'nde yatırılan ek morbiditeli 26 olgu (8 erkek, 18 kadın; ortalama yaş: 30,8 yaş; dağılım 3-74 yıl) değerlendirildi.

\section{BULGULAR}

Yanık hastalarında ek morbiditenin patofizyolojik kaynağ1 önem kazanır. Ek morbiditesi olan yanık hastalarının tedavisi planlanırken eşlik eden morbiditeler akılda bulundurulmalıdır. Tedavinin neticesini sağlamak için, bu hastalara ciddi dikkat harcanmalıdır.

\section{SONUÇ}

Bu yazı Türk toplumunda ek morbiditeli hastalara ait güncel literatürlerin gözden geçirilmesini sağlamakta ve bu özel konuya dikkati çekmektedir.

Anahtar Sözcükler: Yanık; komplikasyon; morbidite.
Burn injury is a multisystemic trauma characterized by a devastating effect on the human body. Burn injury can be observed with an additional premorbid disease in burn injury patients. The pathophysiologic mechanisms of the burn injury may aggravate and influence the progression of the premorbid disease. Additionally, existing systemic diseases can change the progression of the burn injury. ${ }^{[1,2]}$
Patients with weak mental and motor functions are at greater risk than those with normal burn injuries. Victims having sensorimotor deficits are likely to be exposed to more severe burn injuries for a longer period. ${ }^{[3,4]}$

We focus on burn injury cases with pre-exiting para-mental and para-neurological premorbidities.
Departments of ${ }^{1}$ Plastic Reconstructive and Aesthetic Surgery and Burn Center, ${ }^{2}$ General Surgery, Dicle University Faculty of Medicine, Diyarbakir, Turkey.
Dicle Üniversitesi Tıp Fakültesi, ${ }^{1}$ Plastik Rekonstrüktif ve Estetik Cerrahi Anabilim Dalı ve Yanık Merkezi, ${ }^{2}$ Genel Cerrahi Anabilim Dalı, Diyarbakır 
The aim of this article was to determine whether there are differences in the progression, mortality and morbidity of these premorbid patients compared to normal burn injury patients. We also aimed to ascertain whether there are differences in the treatment principles of burn patients with premorbidities.

\section{MATERIALS AND METHODS}

Twenty-six premorbid cases ( 8 males, 18 females; mean age: 30.8 years; range: $3-74$ years) hospitalized in the Burn Center between July 2007 and November 2009 were evaluated. Psychiatric premorbid cases, such as those with personality disorders and psychosis, were not included in the study. The main premorbid etiologies were seizures ( 11 cases), mental retardation ( 5 cases), Down syndrome ( 3 cases), paraplegia ( 3 cases; caused by pes equinovarus deformity in 1 case and motor neuron disease in 2 cases), Parkinson's disease ( 3 cases), and Alzheimer's disease (1 case) (Table $1)$. When the medical history and previous records of these patients were examined, nine of the epileptic cases showed tonic-clonic epilepsy and two showed absence epilepsy. Eight cases were under Epdantoin and the other three were under carbamazepine drug therapy. Six were under regular medication and five were under irregular antiepileptic medical therapy.
The burn etiologies were flame (5 cases), scalding (13 cases), stove contact ( 2 cases), electrical injury (2 cases), falling into the tandir (clay cooker) (2 cases), and water heater ( 2 cases). Most of the cases were exposed to burn injury while undertaking routine home activities.

\section{RESULTS}

Based on the total body surface area (TBSA), the average burn area was $16.3 \%(5-30)$. The burn defects were determined to be second-degree in 16 cases (4 superficial, 12 deep defects) and third-degree in 10 cases. The defects were primarily localized in the upper extremities in 14 cases (Fig. 1). Premorbid cases accounted for $4 \%$ of all the patients (22/541) admitted to our facility during the study period.

In the course of the follow-up period, two of the patients had an aggravated petit mal convulsion due to the devastating effect of the burn injury.

Twenty-four patients underwent surgery, and one patient's defect healed secondarily. One case with Down syndrome had a ventricular septal defect confirmed by echocardiography. The family of this patient rejected surgical treatment.

A perusal of the medical histories of subnormal

Table 1. Demographic features of burn cases with comorbidity

\begin{tabular}{|c|c|c|c|c|c|c|c|c|c|c|}
\hline No & Age & Sex & $\begin{array}{l}\text { Comorbid } \\
\text { etiology }\end{array}$ & $\begin{array}{l}\text { Burn } \\
\text { etiology }\end{array}$ & $\begin{array}{l}\text { Burn } \\
\text { localization }\end{array}$ & $\begin{array}{l}\text { Depth } \\
\text { of burn }\end{array}$ & $\begin{array}{c}\text { TBSA } \\
(\%)\end{array}$ & Progress & Complication & $\begin{array}{l}\text { Hospital } \\
\text { stay (day) }\end{array}$ \\
\hline 1 & 6 & $\mathrm{~F}$ & Down syndrome & Hot water & Face, trunk & $2^{\circ}$ & 15 & Debridement+Grafting & None & 27 \\
\hline 2 & 17 & $\mathrm{~F}$ & Epilepsy & Flame & Cruris & $2^{\circ}$ & 12 & Debridement+Grafting & None & 33 \\
\hline 3 & 65 & $\mathrm{~F}$ & Paraplegia & Electric & Cruris, foot & $2-3^{\circ}$ & 10 & Debridement+Grafting & $\begin{array}{l}\text { Pressure Sore }+ \\
\text { Urethral infection }\end{array}$ & 32 \\
\hline 4 & 74 & $\mathrm{~F}$ & Parkinson & Hot tea & Thigh, cruris & $2^{\circ}$ & 30 & Debridement + Grafting & Weight loss & 36 \\
\hline 5 & 3 & $\mathrm{~F}$ & Down syndrome & Hot food & Face, upper extremity & $2^{\circ}$ & 7 & Debridement+Grafting & None & 30 \\
\hline 6 & 43 & M & Epilepsy & Tandir & Trunk, thigh & $2-3^{\circ}$ & 15 & Debridement+Grafting & None & 34 \\
\hline 7 & 52 & $\mathrm{~F}$ & Epilepsy & Electric & Trunk, upper extremity & $2^{\circ}$ & 18 & Debridement+Grafting & None & 34 \\
\hline 8 & 66 & M & Parkinson & Hot water & Trunk, thigh & $2^{\circ}$ & 25 & Debridement + Grafting & None & 36 \\
\hline 9 & 6 & $\mathrm{~F}$ & Epilepsy & Hot water & Upper extremity & $3^{\circ}$ & 5 & Debridement+Grafting & None & 30 \\
\hline 10 & 5 & M & Down syndrome & Hot food & Trunk, upper extremity & $2-3^{\circ}$ & 15 & Refused the operation & - & 32 \\
\hline 11 & 6 & M & Epilepsy & Hot water & Upper extremity & $2^{\circ}$ & 10 & Healed secondarily & - & 31 \\
\hline 12 & 13 & M & Mental retardation & Flame & Trunk, thigh, cruris & $2^{\circ}$ & 30 & Debridement+Grafting & Partial graft loss & 36 \\
\hline 13 & 65 & $\mathrm{~F}$ & Paraplegia & Stove & Thigh, cruris & $2^{o}$ & 20 & Debridement+Grafting & None & 35 \\
\hline 14 & 57 & $\mathrm{~F}$ & Epilepsy & Flame & Trunk & $2^{\circ}$ & 15 & Debridement+Grafting & None & 32 \\
\hline 15 & 57 & M & Epilepsy & Water boiler & Trunk, upper extremity & $2-3^{\circ}$ & 25 & Debridement+Grafting & None & 33 \\
\hline 16 & 7 & $\mathrm{~F}$ & Mental retardation & Stove & Upper extremity & $2^{\circ}$ & 18 & Debridement + Grafting & Partial graft loss & 35 \\
\hline 17 & 14 & $\mathrm{~F}$ & Mental retardation & Water boiler & Upper extremity, foot & $3^{\circ}$ & 5 & Debridement+Grafting & None & 29 \\
\hline 18 & 6 & M & $\begin{array}{l}\text { Paraplegia } \\
\text { (pes equinovarus) }\end{array}$ & Hot water & Cruris, foot & $2^{\circ}$ & 9 & Debridement+Grafting & None & 36 \\
\hline 19 & 13 & $\mathrm{~F}$ & Mental retardation & Tandir & Thigh, upper extremity & $2-3^{\circ}$ & 12 & Debridement+Grafting & None & 37 \\
\hline 20 & 65 & M & Parkinson & Hot food & Face, upper extremity & $2^{\circ}$ & 16 & Debridement+Grafting & None & 35 \\
\hline 21 & 12 & $\mathrm{~F}$ & Mental retardation & Flame & Trunk, upper extremity & $2^{\circ}$ & 10 & Debridement+Grafting & None & 38 \\
\hline 22 & 65 & $\mathrm{~F}$ & Alzheimer & Hot water & Thigh, cruris & $2-3^{\circ}$ & 25 & Debridement+Grafting & Partial graft loss & 36 \\
\hline 23 & 50 & $\mathrm{~F}$ & Epilepsy & Hot water & Trunk, upper extremity & $3^{\circ}$ & 13 & Debridement+Grafting & None & 34 \\
\hline 24 & 17 & $\mathrm{~F}$ & Epilepsy & Hot water & Face, upper extremity & $2-3^{\circ}$ & 25 & Debridement + Grafting & None & 33 \\
\hline 25 & 4 & $\mathrm{~F}$ & Epilepsy & Flame & Lower extremity & $3^{\circ}$ & 25 & Debridement+Grafting & None & 34 \\
\hline 26 & 13 & $\mathrm{~F}$ & Epilepsy & Hot water & Face, upper extremity & $2-3^{\circ}$ & 15 & Debridement+Grafting & None & 32 \\
\hline
\end{tabular}




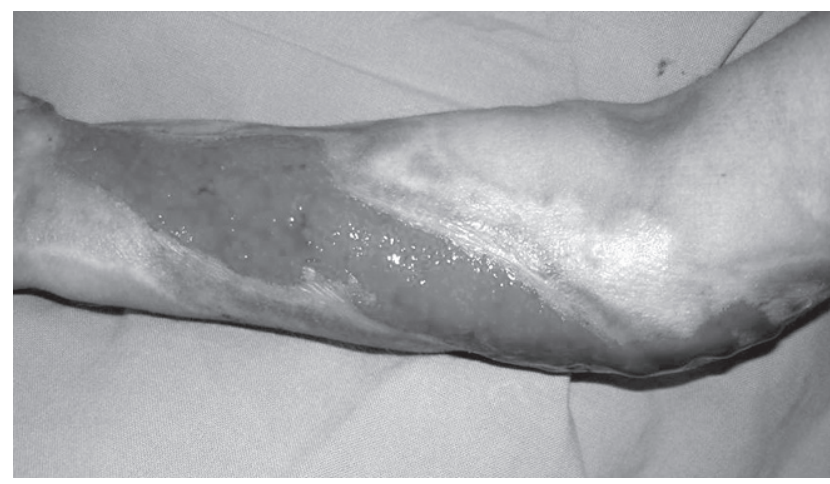

Fig. 1. Preoperative view of the defect in a case with burns of the upper extremity.

mental cases revealed that congenital infections or teratogens may be the etiologic cause. Down syndrome was confirmed by the medical reports submitted by the family. Patients with Down syndrome ranged in age between 3 to 6 years; unfortunately, IQ scores were not obtained in these cases. The rest of the mental retardation cases were over 6 years old, with an IQ level of 70-75.

In 14 of the premorbid cases, early tangential excision and grafting were performed. Full thickness skin grafting was applied to seven cases and split thickness skin grafting to 17 cases (Fig. 2). In two cases with mental retardation, $8 \%$ graft loss was observed due to the hyperactivity of the patients and non-compliance (Fig. 3). In one geriatric case, a 10\% graft failure was attributed to Staphylococcus aureus infection. The overall graft failure ratio was $11.5 \%$. The average hospital stay of premorbid cases was 33.4 days.

\section{DISCUSSION}

Premorbidity can be simply defined as a condition or ailment that occurs or exists before the occurrence of a physical disease or emotional illness. In psychiatry and neurology, the term "premorbid personality" is used to determine the psychological risk factors for the development of a particular disorder. In this article, we investigated the impact of para-neurologic and para-mental premorbidities. The psychotic cases were excluded from our study.

There is a strong association between premorbid cases and burn injury. The premorbid condition can influence the etiologic reasons and the severity of the burn injury. ${ }^{[2]}$ Geriatric and pediatric cases are both prone to burn injury. When neurological or para-neurological premorbid diseases are present, the morbidity and mortality will increase. It is reported in the literature that the severity of the injury is important and the hospital stay is longer. ${ }^{[5]}$

Intellectual disability is characterized by the limitations from a specific emotional or psychological

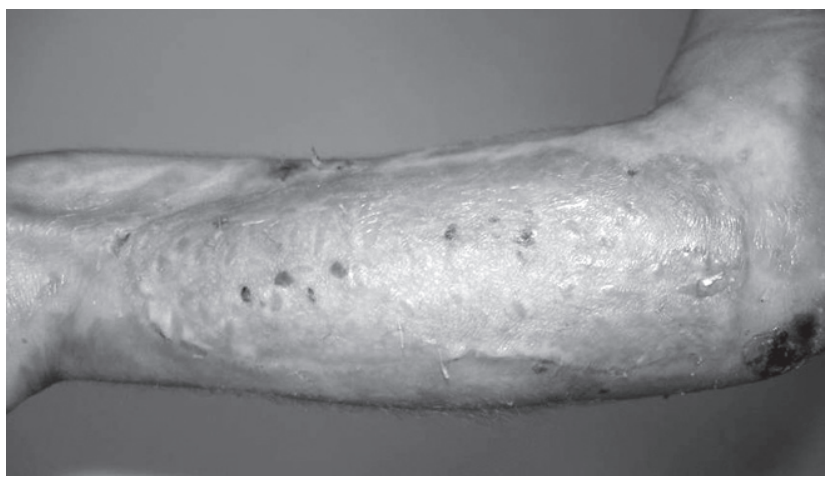

Fig. 2. Postoperative view of a case in whom debridement and grafting were performed.

disability. Intellectual disability may also be used to describe dementing conditions such as Alzheimer's disease.

The management of geriatric burn victims is also a major challenge. In this study, we included six senior patients who were $\geq 65$ years old with pre-existing conditions. The pre-burn functional status and premorbid conditions of these geriatric patients are useful tools for developing an interdisciplinary treatment protocol. The premorbid geriatric burn victims have a higher mortality rate than geriatric patients. ${ }^{[6]}$ In deciding burn treatment, we also needed to focus on the associated pathophysiological conditions. Six of our patients were in the geriatric age range; of these, three

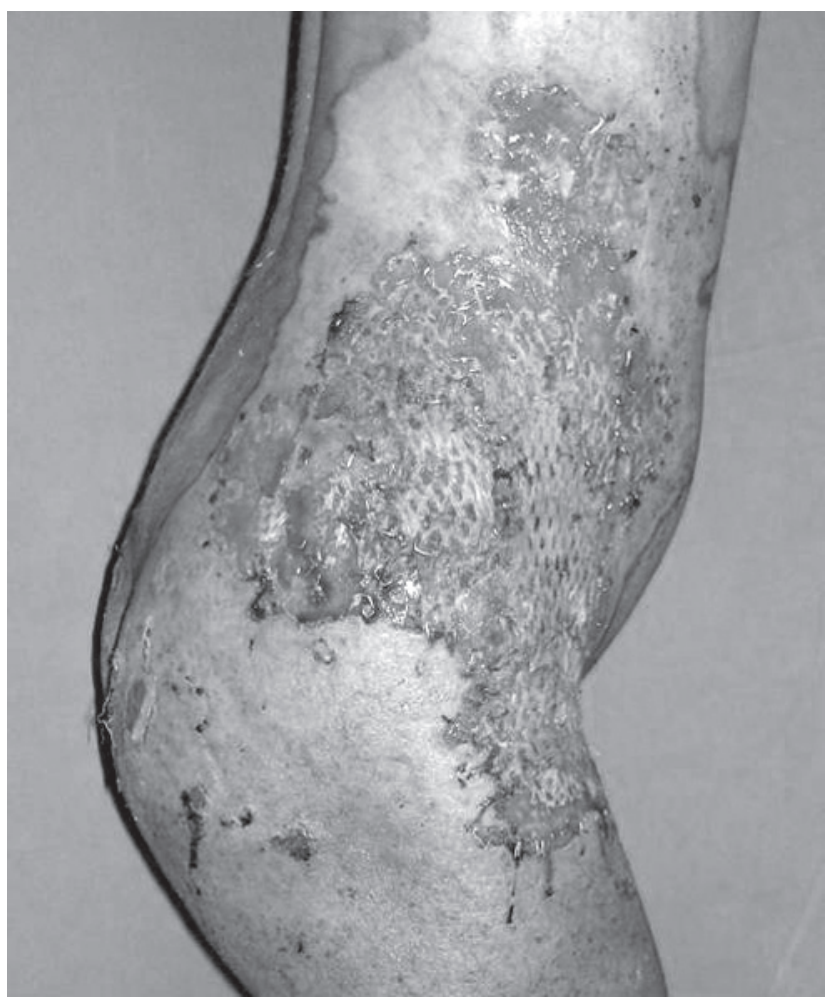

Fig. 3. View of a case with partial graft loss caused by hyperactivity. 
had Parkinson's disease, two had paraplegia and one had Alzheimer's. Four suffered scalding injury.

The ability of elderly patients to grasp or hold objects decreases because of aging tremors and other weaknesses. In addition, their cognitive functions and reflex response to hazardous events wanes and may contribute to burn injuries. The risk increases when premorbidity is also taken into account. In our community, in the presence of cold temperatures, people frequently stand with their extremities close to a burning stove. This is a hazardous action that may cause contact burns. Burns were localized on the lower extremities in premorbid geriatric cases. The mean burn total area was $21 \%$ (range: $10-30 \%$ ). The depths of these injuries were almost the same as with the pediatric cases, but the total area was wider. The mean hospital stay was 35.1 days (32-36 days).

A sub-average intellectual ability is manifested through learning difficulties and social adaptation problems ${ }^{[7]}$ In the literature, it is reported that $2-3 \%$ of the total population is mentally retarded. An IQ level of $<50$ is prevalent in 3.6/1000 live births in the United States population. An equivalent IQ level percentage has not been reported for the Turkish population. ${ }^{[8]}$ Oyeckin, ${ }^{[8,9]}$ in a study limited in number, reported that this rate was about $2.5 \%$. There may be different etiological reasons, such as chromosomal abnormalities, genetic metabolic disorders and genetic neurological disorders. ${ }^{[10]}$

Pediatric cases with neurosensorial motor deficits such as mental retardation or seizures are also at risk for burn injuries. These handicaps make the pediatric population more vulnerable to frequent and serious burn injuries. Of 15 pediatric cases aged between 3 and 17 years, seven cases had scalding burn injury from hot liquids. The epidemiology of pediatric burn injuries in the literature suggests that the most common cause of burns in Turkey is scalding, and the ages of these cases ranged from 1 to 6 years. ${ }^{[11]}$ Children, especially toddlers, are naturally curious and attempt to taste and touch things around them. This instinct can be more intense and often unmanageable in premorbid pediatric cases. ${ }^{[12-14]}$ In this respect, these cases had greater exposure to home accidents compared to the normal pediatric population. Most of our pediatric patients were injured by scalding. There may be different etiological causes for these injuries. However, in the Turkish pediatric population, non-bath scalding is related to contact with the traditional tea-making systems. ${ }^{[15,16]}$ Injuries were usually localized on the upper extremities. The mean total burn area was $14.1 \%$ $-5-30 \%$. The total hospital stay was 32.8 days (27-38 days).

Of the 15 pediatric cases, nine were admitted from rural or urban areas with ignorant parents as the primary caregivers. It is known that children who live in the rural areas of Turkey are at a greater risk for serious burns than those in the cities. Our results indicate that premorbid pediatric patients are highly vulnerable to frequent burn injuries.

Epileptic cases are prone to injuries, fractures, lacerations, and burns. ${ }^{[17,18]}$ In the literature, $42 \%$ of injuries are associated with cooking, which is also more common among females because of their domestic responsibilities. ${ }^{[19-21]}$ In most of our cases, the injuries occurred during bathing. Use of different types of boilers is common in Turkey. However, the majority of water heaters installed in bathrooms are not controlled effectively; some of these devices work with LPG tubes. ${ }^{[22]}$ As excessive heat and humidity may trigger an epileptic attack, scalding injuries may result from the accidental spilling of hot water. ${ }^{[18,23,24]}$ Some of the patients used electric heaters immersed in water; however, these instruments can be dangerous and may cause scalding injuries.

Burn injury was observed frequently on the upper extremities and on the trunk in epileptic cases. These cases were exposed to burn injury while undertaking domestic activities such as having a bath. The mean total burn area was $16.1 \%$ (range: $7-30 \%$ ). The total hospital stay was 32.7 days (30-34 days).

The longer hospital stay observed among premorbid patients is associated with several factors. ${ }^{[5]}$ The average hospital stay of premorbid cases in our study was 33.4 days. To our knowledge, there is no detailed study about premorbid cases and the length of their hospital stay. Further in-depth research is needed. Moreover, special care should be taken in the treatment of the burn injury cases with premorbidity.

Prevention measures also need to be integrated with day-to-day activities. For example, the tubs used must have levers to regulate the water temperature. In the event of a seizure attack, the victim can hit the lever arm and avoid exposure to hot water. A scalding injury is more likely when the water is warmer than $43{ }^{\circ} \mathrm{C} \cdot{ }^{[21]}$ Safety devices that limit the water temperature are recommended. In the homes of pediatric premorbid patients, water heaters should be set at $37.7^{\circ} \mathrm{C}$ $\left(100^{\circ} \mathrm{F}\right)$; in the case of other adults, these devices can be set to $48.8-51.6^{\circ} \mathrm{C}\left(120-125^{\circ} \mathrm{F}\right) .{ }^{[25]}$

Special care and additional measures should be taken in the treatment of burn injury patients with premorbidity. Psychological, neurological and geriatric causes are factors that may affect recovery from the burn injury or the success of the operation. A detailed evaluation of coexisting disorders and additional care are key points in the treatment of comorbid burn patients. Burn prevention materials targeting the premor- 
bid patient population remain relatively scarce in Turkey. Therefore, health organizations need to focus on providing basic and lifesaving information to patients and their families.

\section{REFERENCES}

1. Uygur F, Özyurt M, Evinç R, Hosbul T, Çeliköz B, Haznedaroğlu T. Comparison of octenidine dihydrochloride

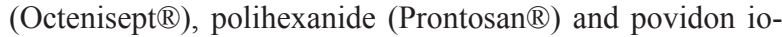
dine (Betadine $\left.{ }^{\circledR}\right)$ for topical antibacterial effects in Pseudomonas aeruginosa-contaminated, full-skin thickness burn wounds in rats. CEJMed 2008;3:417-21.

2. Germann G, Barthold U, Lefering R, Raff T, Hartmann B. The impact of risk factors and pre-existing conditions on the mortality of burn patients and the precision of predictive admission-scoring systems. Burns 1997;23:195-203.

3. Alden NE, Rabbitts A, Rolls JA, Bessey PQ, Yurt RW. Burn injury in patients with early-onset neurological impairments: 2002 ABA paper. J Burn Care Rehabil 2004;25:107-11.

4. Ramirez RJ, Behrends LG, Blakeney P, Herndon DN. Children with sensorimotor deficits: a special risk group. J Burn Care Rehabil 1998;19:124-7.

5. Thombs BD, Singh VA, Halonen J, Diallo A, Milner SM. The effects of preexisting medical comorbidities on mortality and length of hospital stay in acute burn injury: evidence from a national sample of 31,338 adult patients. Ann Surg 2007;245:629-34.

6. Rao K, Ali SN, Moiemen NS. Aetiology and outcome of burns in the elderly. Burns 2006;32:802-5.

7. Patterson DR, Finch CP, Wiechman SA, Bonsack R, Gibran N, Heimbach D. Premorbid mental health status of adult burn patients: comparison with a normative sample. J Burn Care Rehabil 2003;24:347-50.

8. Roeleveld N, Zielhuis GA, Gabreëls F. The prevalence of mental retardation: a critical review of recent literature. Dev Med Child Neurol 1997;39:125-32.

9. Oyekcin DG. Sociodemographic features and psychiatric diagnosis of the patients who referred to an East Anatolian city hospital's psychiatry policlinic during one year period. (Bir devlet hastanesi psikiyatri polikliniğine bir yıl içinde başvuran olguların sosyodemografik özellikleri ve psikiyatrik tanı dağılımı) (Article in Turkish). Anadolu Psikiyatri Dergisi 2008;9:39-43.

10. Barret JP, Gomez P, Solano I, Gonzalez-Dorrego M, Crisol FJ. Epidemiology and mortality of adult burns in Catalonia.
Burns 1999;25:325-9.

11. Sakallioğlu AE, Başaran O, Tarim A, Türk E, Kut A, Haberal M. Burns in Turkish children and adolescents: nine years of experience. Burns 2007;33:46-51.

12. Kumar P, Chirayil PT, Chittoria R. Ten years epidemiological study of paediatric burns in Manipal, India. Burns 2000;26:261-4.

13. Fukunishi K, Takahashi H, Kitagishi H, Matsushima T, Kanai $\mathrm{T}$, Ohsawa $\mathrm{H}$, Epidemiology of childhood burns in the critical care medical center of Kinki University Hospital in Osaka, Japan. Burns 2000;26:465-9.

14. Lin TM, Wang KH, Lai CS, Lin SD. Epidemiology of pediatric burn in southern Taiwan. Burns 2005;31:182-7.

15. Tarim A, Nursal TZ, Yildirim S, Noyan T, Moray G, Haberal M. Epidemiology of pediatric burn injuries in southern Turkey. J Burn Care Rehabil 2005;26:327-30.

16. Kut A, Basaran O, Noyan T, Arda IS, Akgün HS, Haberal M. Epidemiologic analysis of patients with burns presenting to the burn units of a University Hospital Network in Turkey. J Burn Care Res 2006;27:161-9.

17. Beghi E. Accidents and injuries in patients with epilepsy. Expert Rev Neurother 2009;9:291-8.

18. Josty IC, Narayanan V, Dickson WA. Burns in patients with epilepsy: changes in epidemiology and implications for burn treatment and prevention. Epilepsia 2000;41:453-6.

19. Bekerecioğlu M, Yüksel F, Peker F, Karacaoğlu E, Durak N, Kişlaoğlu E. "Tandir": an old and well known cause of burn injury in the Middle East. Burns 1998;24:654-7.

20. Akçay MN, Oztürk G, Aydinli B, Ozoğul B. Tandir burns: a severe cause of burns in rural Turkey. Burns 2008;34:268-70.

21. Unglaub F, Woodruff S, Demir E, Pallua N. Patients with epilepsy: a high-risk population prone to severe burns as a consequence of seizures while showering. J Burn Care Rehabil 2005;26:526-8.

22. Shoufani A, Golan J. Shabbes burn, a burn that occurs solely among Jewish orthodox children; due to accidental shower from overhead water heaters. Burns 2003;29:61-4.

23. Spitz MC. Severe burns as a consequence of seizures in patients with epilepsy. Epilepsia 1992;33:103-7.

24. Hampton KK, Peatfield RC, Pullar T, Bodansky HJ, Walton C, Feely M. Burns because of epilepsy. Br Med J (Clin Res Ed) 1988;296:1659-60.

25. Feldman KW, Schaller RT, Feldman JA, McMillon M. Tap water scald burns in children. 1997. Inj Prev 1998;4:238-42. 